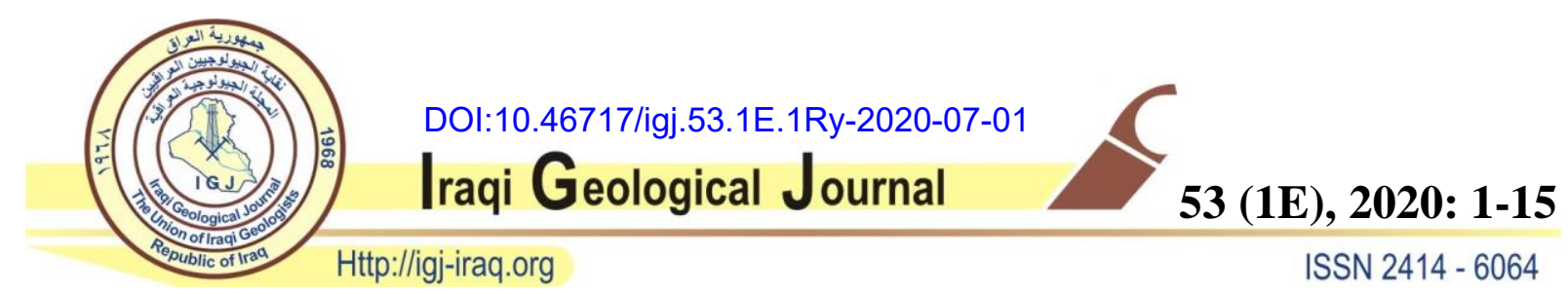

\title{
RESERVOIR MODELING FOR MISHRIF FORMATION IN NASIRIYAH OILFIELD
}

\author{
${ }^{1}$ Huda D. Khalaf Al-Mozan* and ${ }^{1}$ Mohammed S. Al-Jawad \\ ${ }^{1}$ Department of Petroleum, College of Engineering, University of Baghdad, Baghdad, Iraq \\ "E-mail: hudadaaj99@yahoo.com \\ Received: 7 Feberuary 2020; accepted: 28 March 2020
}

\begin{abstract}
Building a reservoir model is very important in the petroleum industry where it is considered the basic step for putting development plans of the field. The formation under study is Mishrif Formation in Nasiriyah oil field. To achieve a reasonable reservoir model that gives the actual performance, it is necessary to validate the model before using it for field development plans and this can be fulfilled by initialization results and history matching. This study involves building a reservoir model and validating it for Nasiriyah oilfield. Initial conditions including initial pressure, datum depth, and oil-water contact were used in the simulator. Oil-water contact is represented in the model as a surface. Fluid properties comprise of water and oil properties were employed for model construction. The validity of initialization results is achieved by a comparison between Oil Initially in Place (OIIP) values resulting from the geological model and reservoir model. The period of history matching is about ten years. The available production and pressure data were fed into the simulator. History matching is divided into three parts: production matching, pressure matching, and water cut matching. Good matching was resulted between calculated production rates by the simulator and observed production rates. Many runs of the simulator were conducted to obtain matching. Pressure matching is verified between calculated pressure by the simulator and the observed static pressure of the wells after multiplying the horizontal permeability by a factor 3.4. The field did not record water production during its production period and this was confirmed during history matching. The reservoir performance of Nasiriyah oil field indicated that the water drive is weak and the reservoir needs to support.
\end{abstract}

Keywords: Reservoir modeling; Nasiriyah oilfield; History matching; Pressure

\section{INTRODUCTION}

Reservoir modeling is a mathematical representation of fluid flow through porous media, usually in form partial differential equation incorporates Darcy's law, material balance, rock 
and fluid properties (Islam et al., 2016). It is necessary for optimizing hydrocarbon recovery, predicting the phase of the fluid, saturation, pressure, production rate and bottom- hole pressure (BHP) through the time period, and providing a starting point for putting development plans of the field (Satter and Iqbal, 2016). The reservoir is modeled by incorporating dynamic data into a geological model which is composed of an individual of grids; each block has petrophysical and fluid properties. There is no change in property through a block, where each grid has an average property. The flow rate between adjacent cells is specified by the pressure difference between them, change in pressure and saturation through the reservoir is calculated over a time period. Dynamic model accuracy is affected by time steps and the number of grid blocks (Mattax and Dalton, 1990). Limited data available in early time will increase uncertainty in the estimation of reservoir behavior. Reducing uncertainty is obtained when additional information is added to the dynamic model. Updating reservoir modeling with new data improves performance, prediction of the reservoir, and displacement process and accurate field development (Kortekaas, 1998). (Abbas and Mahdi, 2020) mentioned that the petrophysical heterogeneity of the reservoir units within the Mishrif Formation is due to variations in porosity, water saturation and fluid volume. (Al- Baldawi, 2020) mentioned that the knowledge of the porosity-velocity association in carbonates can be used to establish wireline-log interpretation by predicting other parameters, such as pore size, diagenesis, and porosity patterns, in addition to parameters measured by wireline. The process of calibrating the simulation model is called history matching. The main purpose of it is improving and validating the reservoir simulation model to give reasonable future predictions under different development strategies by reducing the risk related to decisions that are made under the inevitable backdrop of uncertainty data (Gilman and Ozgen, 2013).

\section{STUDY AREA}

Nasiriyah oilfield is located to the east of the Euphrates river, about $38 \mathrm{~km}$ northwest of the Nasiriyah city. It was discovered in 1975 through a seismic survey, which was done by Iraq South Oil Company. The dimensions of the field are $34 \mathrm{~km}$ in length and $13 \mathrm{~km}$ in width. The structure is a longitudinal anticline with the northwest-southeast axis direction. The flanks' dip is very small toward the northeast and southwestern about $\left(1^{\circ}-2^{\circ}\right)$. The field is located in the south of Iraq between latitudes $\left(34^{\circ} 80^{\prime}-34^{\circ} 60^{\prime}\right) \mathrm{N}$ and longitudes $\left(57^{\circ} 50^{\prime}-60^{\circ} 10^{\prime}\right) \mathrm{E}$. The first exploration well was drilled in 1978 and the results showed a good hydrocarbon existing in Mishrif, NuhrUmr, and Yamama formations, then four evaluation wells were drilled to determine oil field extension. All the first five wells were drilled from the duration 
1978 to 1987 . The drilling was resumed after 2010. The Mishrif Formation consists of bioclastic limestone rock and chalky limestone, the average thickness of this formation is about 170 m (EOC, 2001). The Mishrif Formation consists of two parts: upper Mishrif (MA) and lower Mishrif (MB) separated by shale. Oil is found in lower Mishrif and upper Mishrif is almost water zone. The Mishrif Formation in Nasiriyah oil field is overlain by the Kifl Formation with conformity contact and the lower contact of the formation is underlain by the Rumaila limestone formation (ENI Company, 2007). The Mishrif reservoir is a formation, a latest Cenomanian - Early Turonian in age is a regional shallow water limestone succession that shoals upward, due to progradation, from basinal deposits (Al-Mimar, 2018).

Table 1. OWC for Nasiriyah oilfield wells

\begin{tabular}{|c|c|}
\hline Well & OWC $(\mathrm{m})$ \\
\hline NS-1 & 2073 \\
\hline NS-2 & 2069 \\
\hline NS-3 & 2075 \\
\hline NS-4 & 2065 \\
\hline NS-5 & 2056 \\
\hline NS-6 & 2062 \\
\hline NS-7 & 2061 \\
\hline NS-9 & 2058 \\
\hline NS-10 & 2060 \\
\hline NS-15 & 2045 \\
\hline
\end{tabular}

\section{METHODOLOGY}

\section{Initial Condition}

The initial conditions that were used in building the model for the reservoir are:

- The initial reservoir pressure of 3698 psi at a datum depth of $2040 \mathrm{~m}$.

- Bubble point pressure $(\mathrm{Pb})$ of 2226 psi.

- The studied area with no flow at outer boundaries (closed reservoir).

\section{Oil-Water Contact (OWC)}

It is calculated from well log interpretation for wells, where it is selected at $\mathrm{Sw}=100 \%$ of all wells and represented it as a surface in the model. There is variation in OWC depth where the eastern part of the field is higher level than the middle and west parts, where its depth at well NS-15 is $2045 \mathrm{~m}$ while at well NS-3 is $2075 \mathrm{~m}$,Table 1, and (Fig.1.)

\section{Grid System}

The Mishrif Formation was represented by a three-dimensional grid system $(139 \times 77 \times 67)$ in I, $\mathrm{J}$ and $\mathrm{K}$ direction, where the grid size is $180 \mathrm{~m}$ in width and $180 \mathrm{~m}$ in length and the total number of cells is 717101 . 


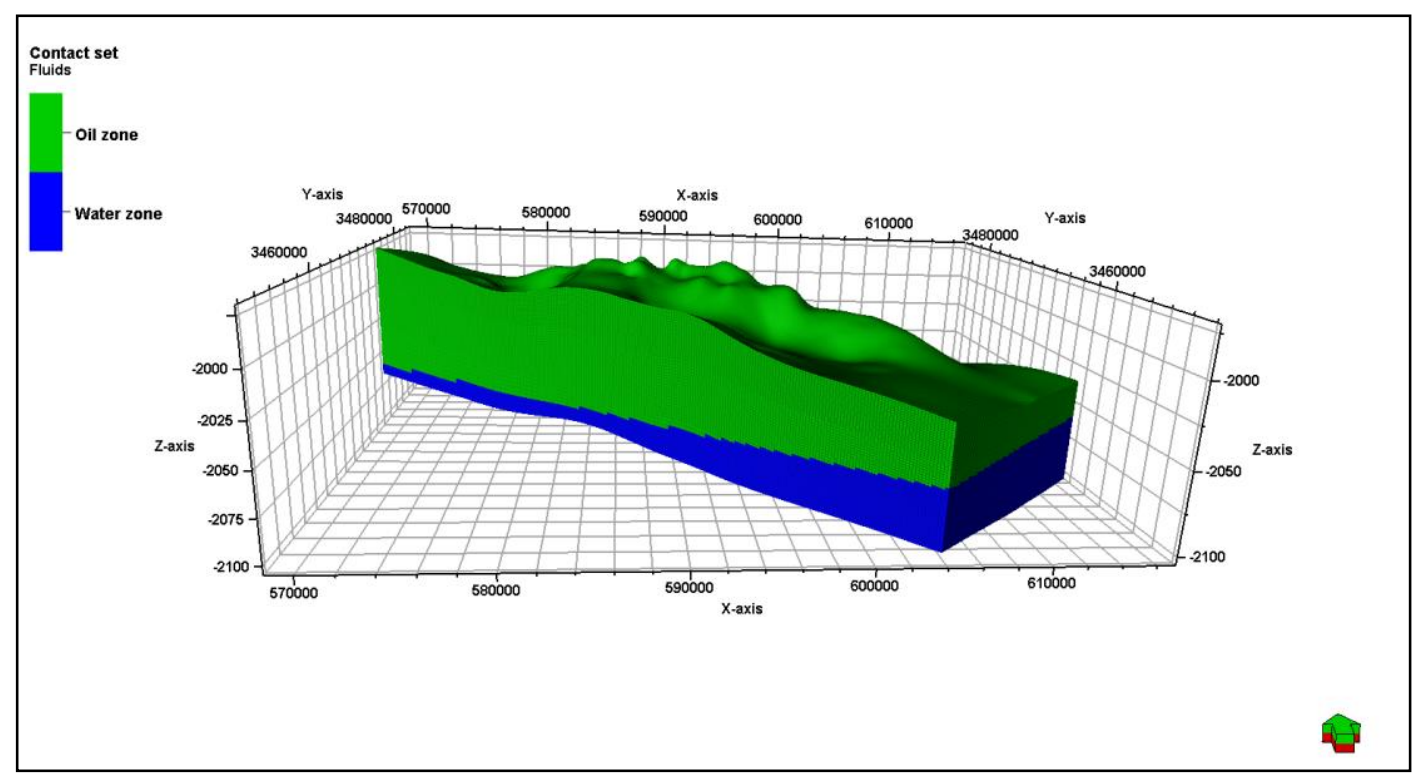

Fig. 1. OWC of the Mishrif Formation

Each unit in the Mishrif Formation is divided into layers. The nonreservoir units (Top Mishrif, MA and Shale) are divided into eight layers for top Mishrif, eight layers for MA, and one layer for shale. The reservoir units (MB1-a, MB1-b, and MB2), the main reservoir units are MB1-a and MB1-b due to its petrophysical properties (low water saturation and high effective porosity). Although MB2 is a reservoir unit, it contains a low amount of oil due to its high water saturation. Reservoir units (MB1-a, MB1-b, and MB2) are divided into twenty layers for MB1-a, twenty layers for MB1-b, and ten layers for MB2. The total layers of Mishrif Formation are sixty-seven layers.

\section{Formation Compressibility}

Rock compressibility for the Mishrif Formation was calculated using Hall correlation (Ahmed, 2019) at an average porosity value 0.1658 and its value is $3.9 * 10^{-6} \mathrm{psi}^{-1}$ as below:

$\mathrm{Cf}=\left(1.782 / \emptyset^{0.438}\right) * 10^{-6}$

\section{Formation Water Properties}

The properties of formation water which are recovered from the evaluation of well tests for wells (NS-1and NS-2) are shown in Table 2. The average density and average salinity of water formation that were used in the model are $1.14 \mathrm{gm} / \mathrm{cc}$ and $193235 \mathrm{ppm}$, respectively.

Table 2. Formation water properties

\begin{tabular}{|c|c|c|}
\hline Well name & NS-1 & NS-2 \\
\hline Specific gravity in 60/60 ${ }^{0} \mathrm{~F}$ & 1.1226 & 1.1627 \\
\hline $\mathrm{CL}^{-1}(\mathrm{ppm})$ & 96965 & 144840 \\
\hline TDS $(\mathrm{ppm})$ & 183779 & 202691 \\
\hline $\mathrm{PH}$ & 4.8 & 5.79 \\
\hline Rw @ $60{ }^{\circ} \mathrm{F}$ & 0.022 & 0.02 \\
\hline
\end{tabular}




\section{Water Formation Volume Factor}

The water formation volume factor $(\mathrm{Bw})$ for the Mishrif Formation was calculated using McCain correlation (McCain, 1991), as 1.02 bbl/STB.

\section{Water Compressibility}

Water compressibility $\left(\mathrm{C}_{\mathrm{w}}\right)$ of the Mishrif Formation was calculated at $\mathrm{T}=165^{\circ} \mathrm{F}, \mathrm{S}=220287.9$ $\mathrm{mg} / \mathrm{L}$ and $\mathrm{p}=3698 \mathrm{psi}$ and its value was $2.1 \times 10^{-6} \mathrm{psi}^{-1}$ as below (McCain, 1991):

$\mathrm{Cw}=1 /(7.033 \mathrm{p}+0.5415 \mathrm{~S}-537.0 \mathrm{~T}+403300)$

\section{Oil Properties}

Basic oil properties were used as PVT input data for the reservoir simulation model in the simulator.

\section{PVT Data}

Seven samples for the Mishrif Formation were assembled for NS-1, NS-2, NS-3, NS-4, and NS-5 wells, then the best sample is chosen which represents the physical and thermodynamic properties for the Mishirf reservoir in the reservoir model. The sample from well NS-1 at depth $2000 \mathrm{~m}$ represents the best sample was chosen in the reservoir model due to its gas-oil ratio (GOR) value which represents the average value as well as the value of the oil formation volume factor $\left(\mathrm{B}_{\mathrm{O}}\right)$ and oil viscosity $(\mu \mathrm{o})$. PVT data utilized in the simulation model are shown in Table 3.

Table 3. PVT for well NS-1

\begin{tabular}{|c|c|c|c|}
\hline $\mathrm{P}(\mathrm{psia})$ & GOR $(\mathrm{Scf} / \mathrm{STB})$ & $\mathrm{B}_{\mathrm{O}}(\mathrm{RB} / \mathrm{STB})$ & $\mu \mathrm{O}(\mathrm{cP})$ \\
\hline 4978 & 551 & 1.2815 & 1.577 \\
\hline 2226 & 551 & 1.3143 & 1.2236 \\
\hline 1849 & 460 & 1.2714 & 1.2727 \\
\hline 1565 & 402 & 1.2474 & 1.4344 \\
\hline 1280 & 345 & 1.2241 & 1.6576 \\
\hline 996 & 291 & 1.2016 & 1.9166 \\
\hline 711 & 231 & 1.1769 & 2.223 \\
\hline 427 & 168 & 1.151 & 2.5294 \\
\hline 142 & 89 & 1.111 & 2.8358 \\
\hline 14.7 & 0 & 1.0434 & 2.9737 \\
\hline
\end{tabular}

\section{Relative Permeability (kr) and Capillary Pressure (Pc)}

Three capillary pressures and three relative permeability curves are employed in the simulation model. According to the sample's depth, each unit has a capillary pressure and relative permeability curves. The relative permeability curves and capillary pressure curves are shown in Figs. 2 and 3, respectively. 


\section{RESULTS AND DISCUSSION}

\section{Initialization Results}

The important step of the simulation is to determine OIIP using geological and dynamic models. The comparison between OIIP values resulting from the geological model (volumetric method) and reservoir model is necessary to check the validation of the model. Oil initially in place (OIIP) was calculated by the simulator using the dynamic method is $9.801 \times 10^{9}$ STB while OIIP calculated previously by using the volumetric method was $9.46 \times 10^{9} \mathrm{STB}$, the error percentage between them is $4 \%$.

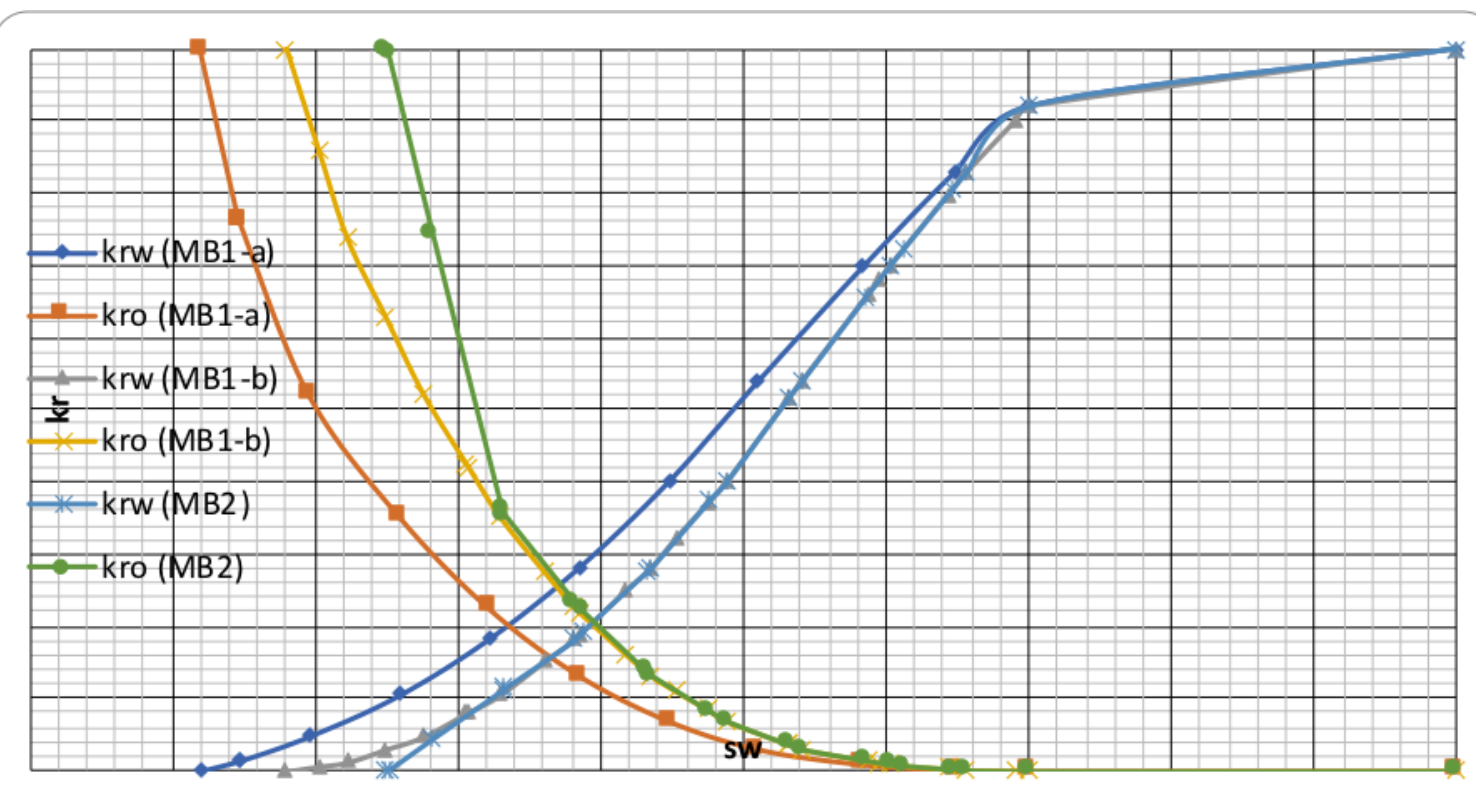

Fig. 2. Relative permeability curves

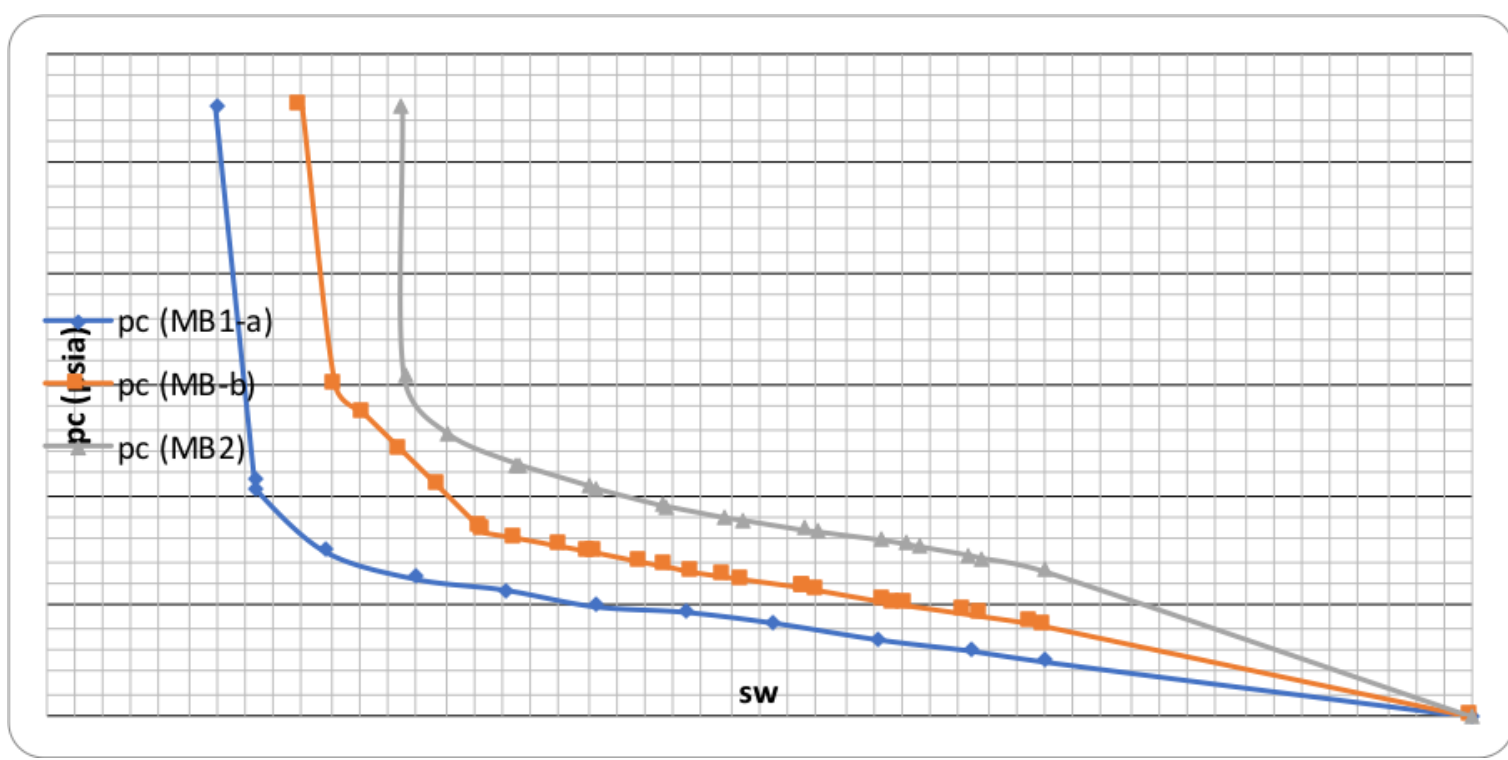

Fig. 3. Capillary pressure curves 


\section{History Matching}

The Mishrif Formation in Nasiriyah Oilfield has relatively short-term historical production, where the actual production started in August 2009 with production rate $68000 \mathrm{STB} / \mathrm{d}$ then the production increased to about $86000 \mathrm{STB} /$ day in 2018. Twenty-five wells were opened to flow. The period of history matching is about ten years. The available pressure measurements do not cover all historical production periods, the availability of production and pressure measurements were fed into the simulator.

\section{Production Matching}

Monthly oil production rates and operating days are entered into the program. All wells are verified the actual production rate. A good matching resulted between the calculated production rates by the simulator and the observed production rates as shown in Figs. 4,13 and 14.

\section{Well Block Pressure Matching}

The pressure matching process was restricted to match only the static pressures from modular formation dynamic tests (MDT) for some wells that are chosen according to the availability of pressure measurements. Many runs of the simulator were conducted to obtain matching. History matching is verified between calculated pressure by the simulator and the observed static pressure of the wells after multiplying the horizontal permeability by a factor of 3.4 as shown in Fig. 4 through Fig. 13. History matching of field pressure is shown in Fig. 15, there is a small discrepancy in the field pressure matching because the observed pressure data is represented only the area of the wells while the field pressure is calculated for the total area of the field. The discrepancies between simulated field pressure and observed data are noticed for the wells produced for a long time or with high oil production.

\section{Water Cut Matching}

The field does not record water production during its production period and this is confirmed during history matching as shown in Fig. 4 through Fig. 13. Although the period of the history matching is short about ten years, the reservoir shows a high-pressure drop at the end of the period of history matching especially in the middle of the field to the northwest (depleted area) compared to the initial pressure of the reservoir (Fig.16). This behavior indicates that the reservoir is produced under the volumetric drive. Fig. 17 shows the pressure distribution at the end of the history matching period 


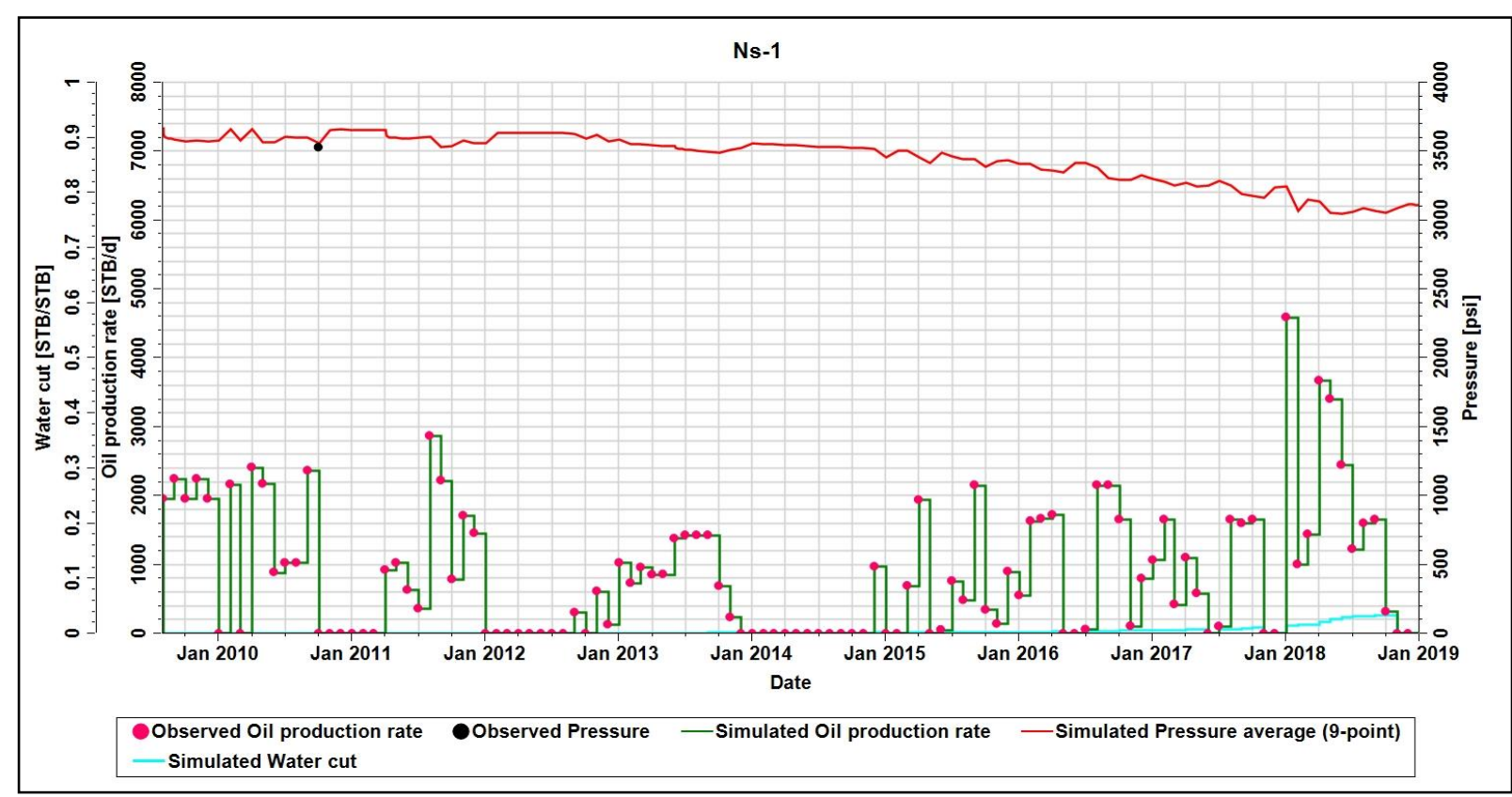

Fig. 4. History matching for well NS-1

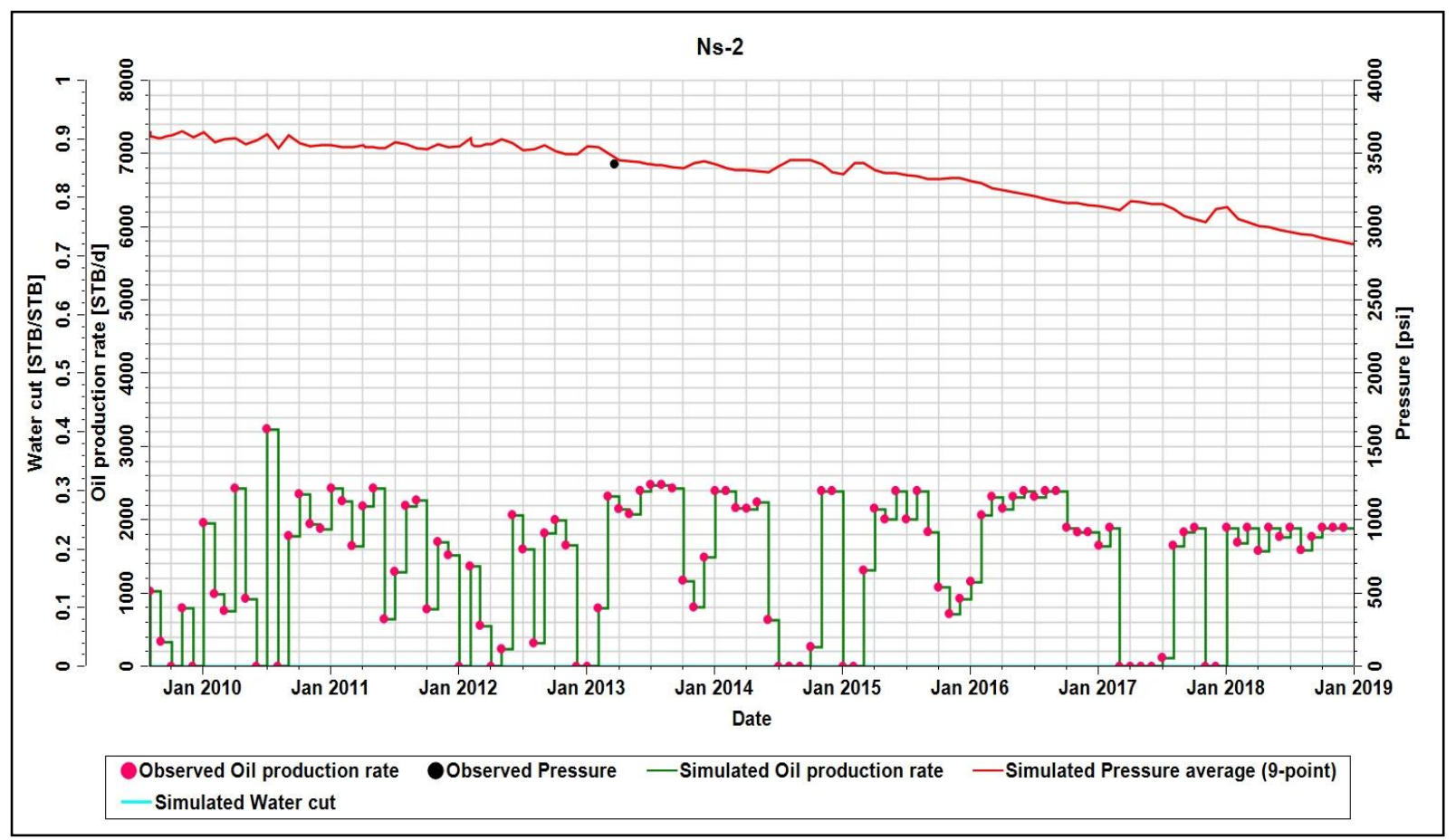

Fig. 5. History matching for well NS-2 




Fig. 6. History matching for well NS-3

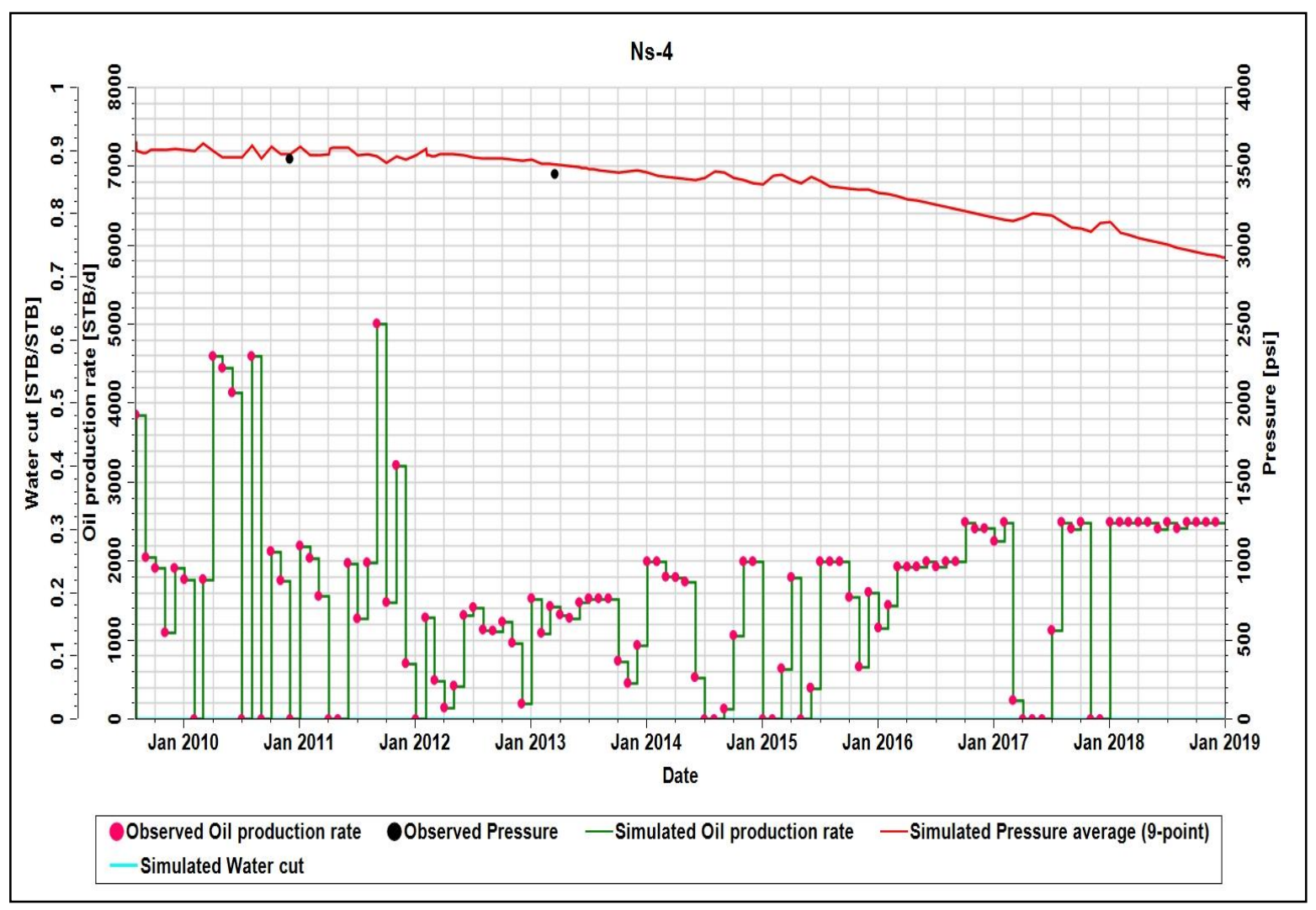

Fig. 7. History matching for well NS-4 


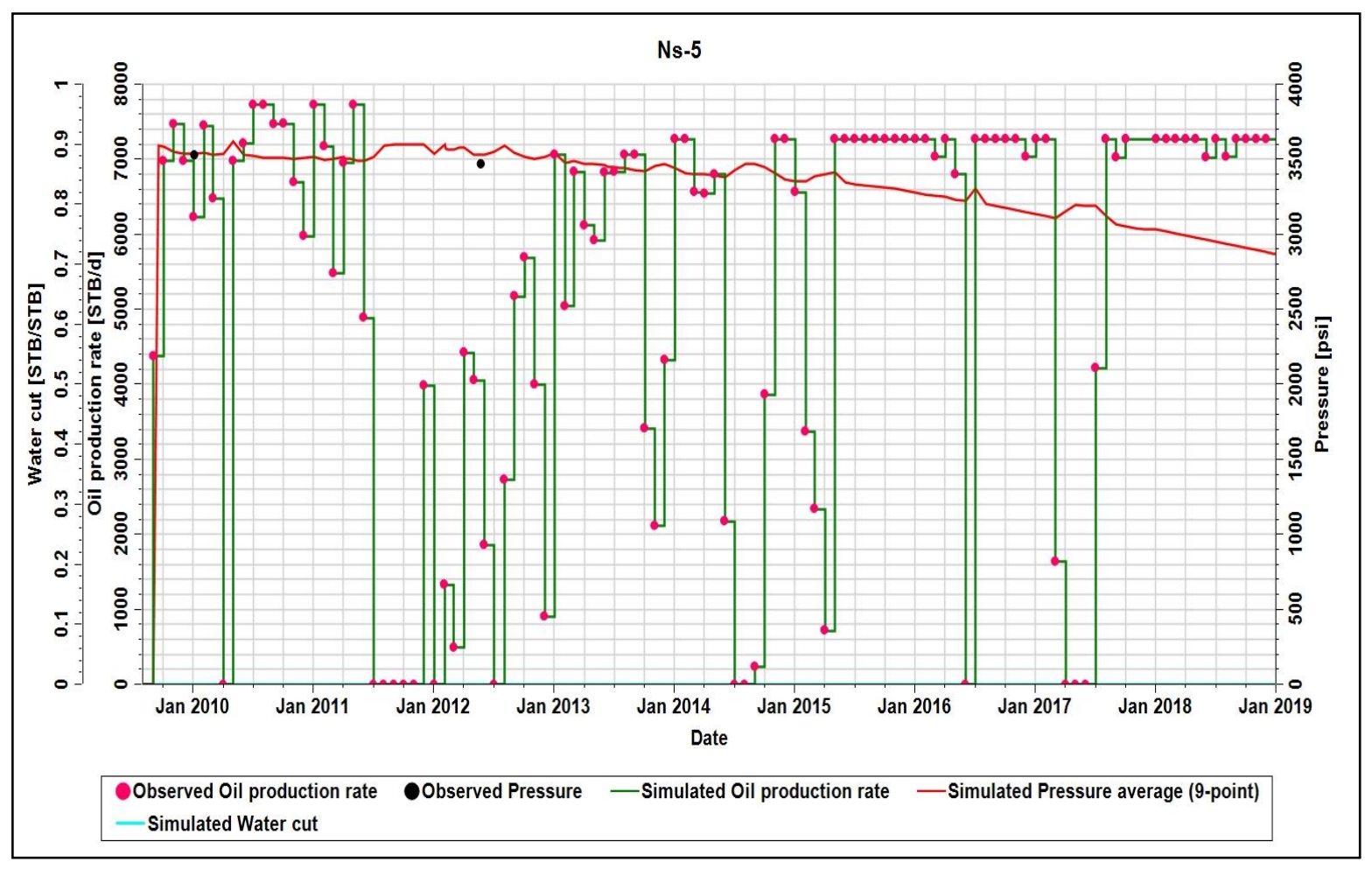

Fig. 8. History matching for well NS-5

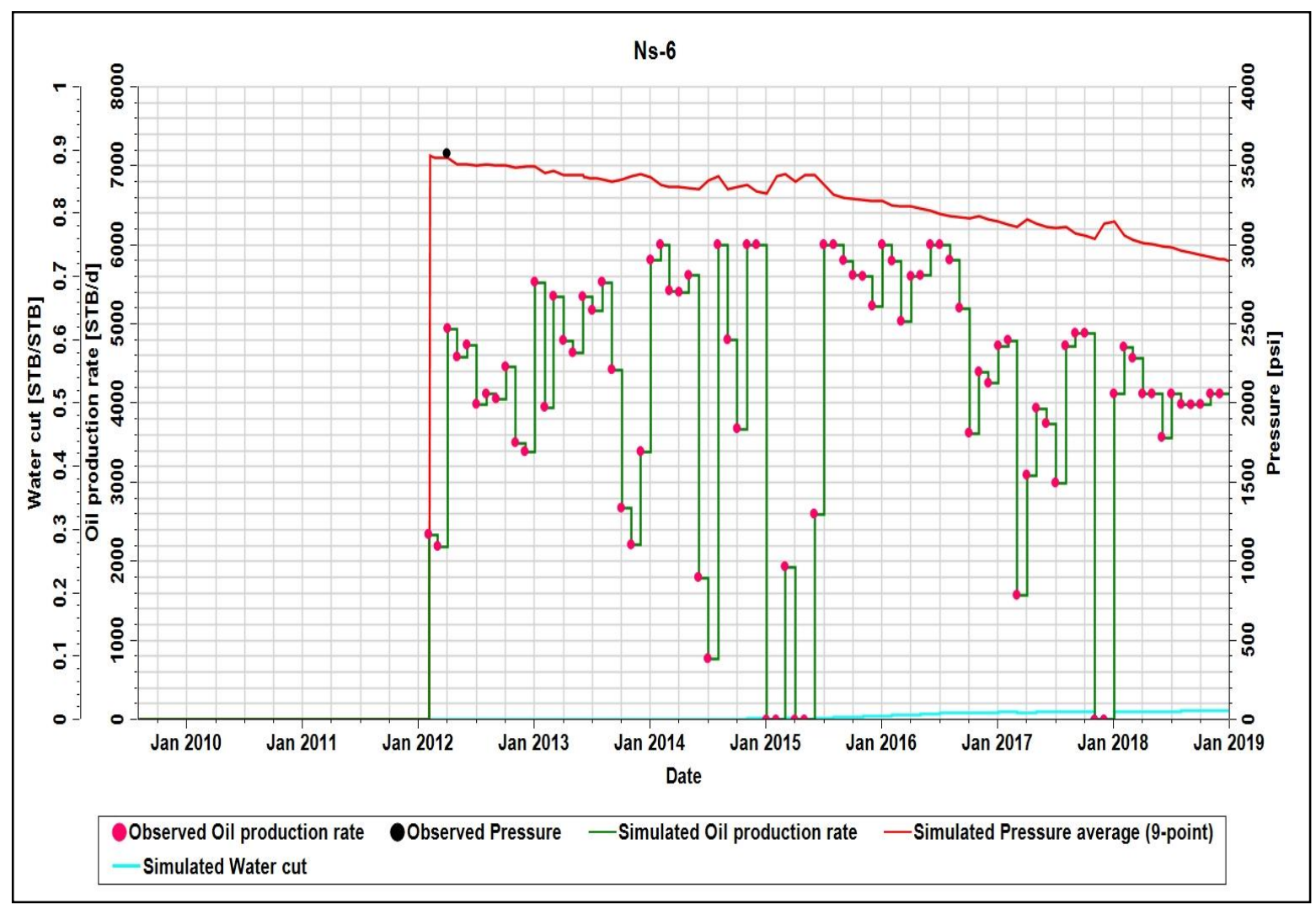

Fig. 9. History matching for well NS-6 


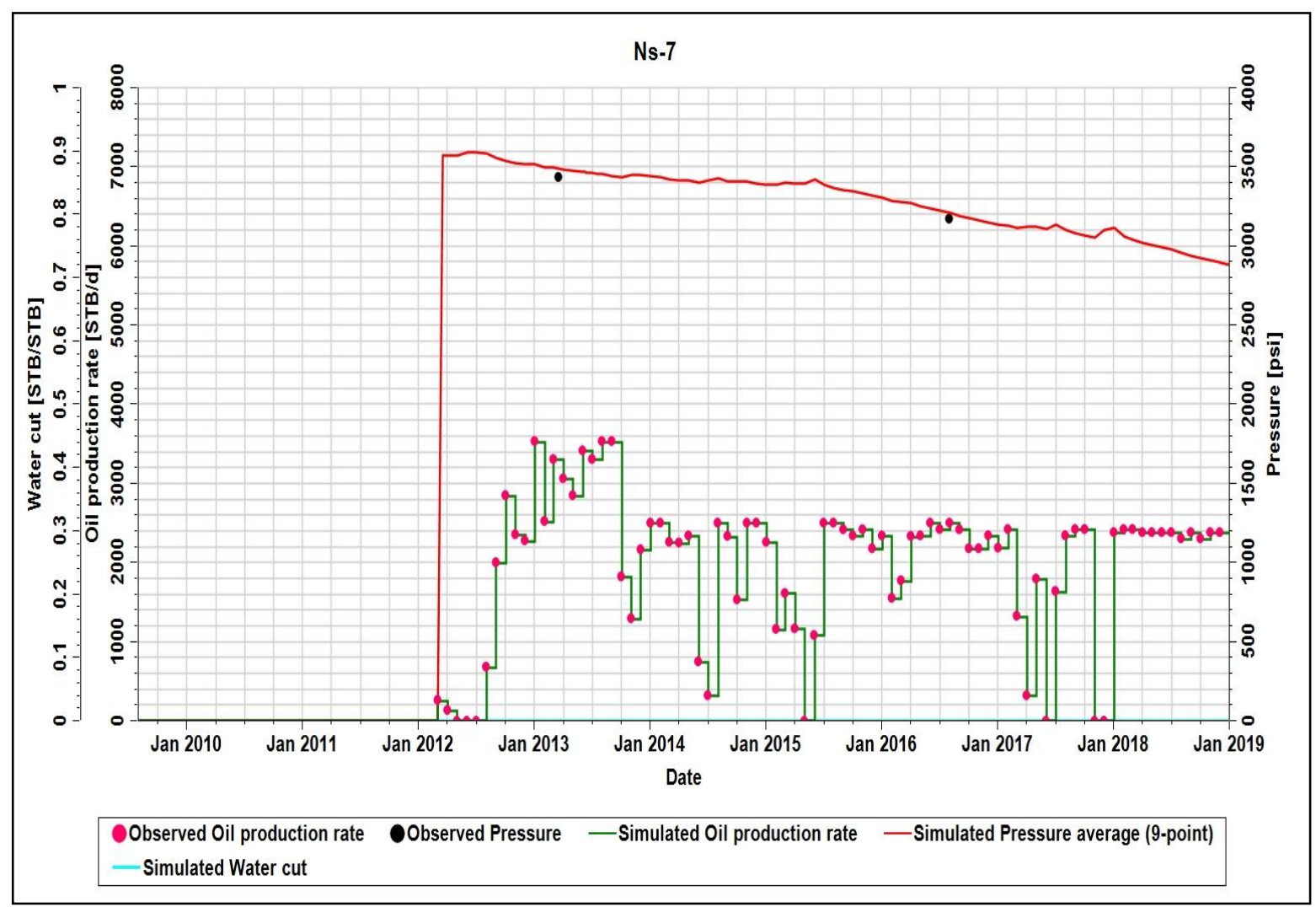

Fig. 10. History matching for well NS-7

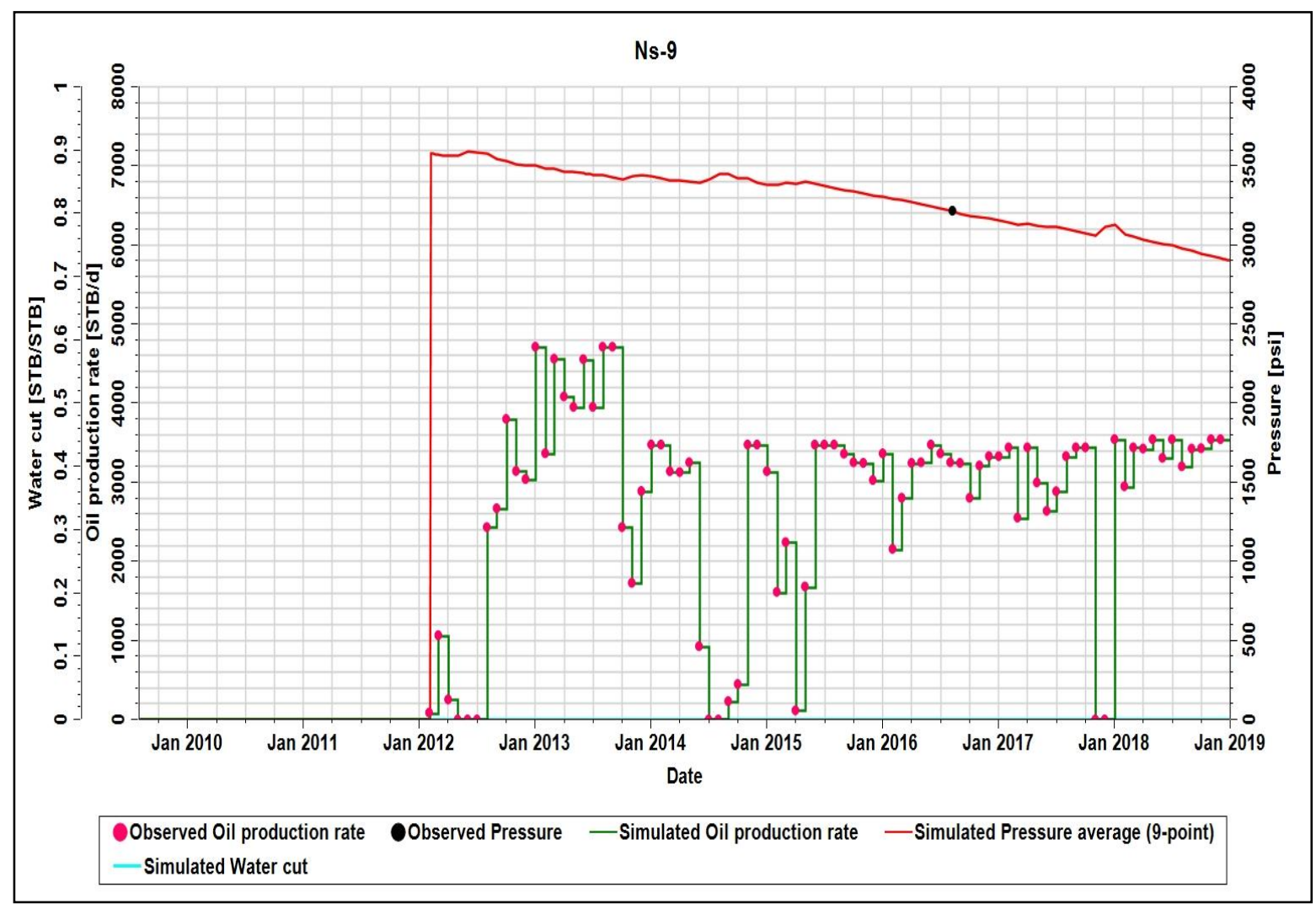

Fig. 11. History matching for well NS-9 


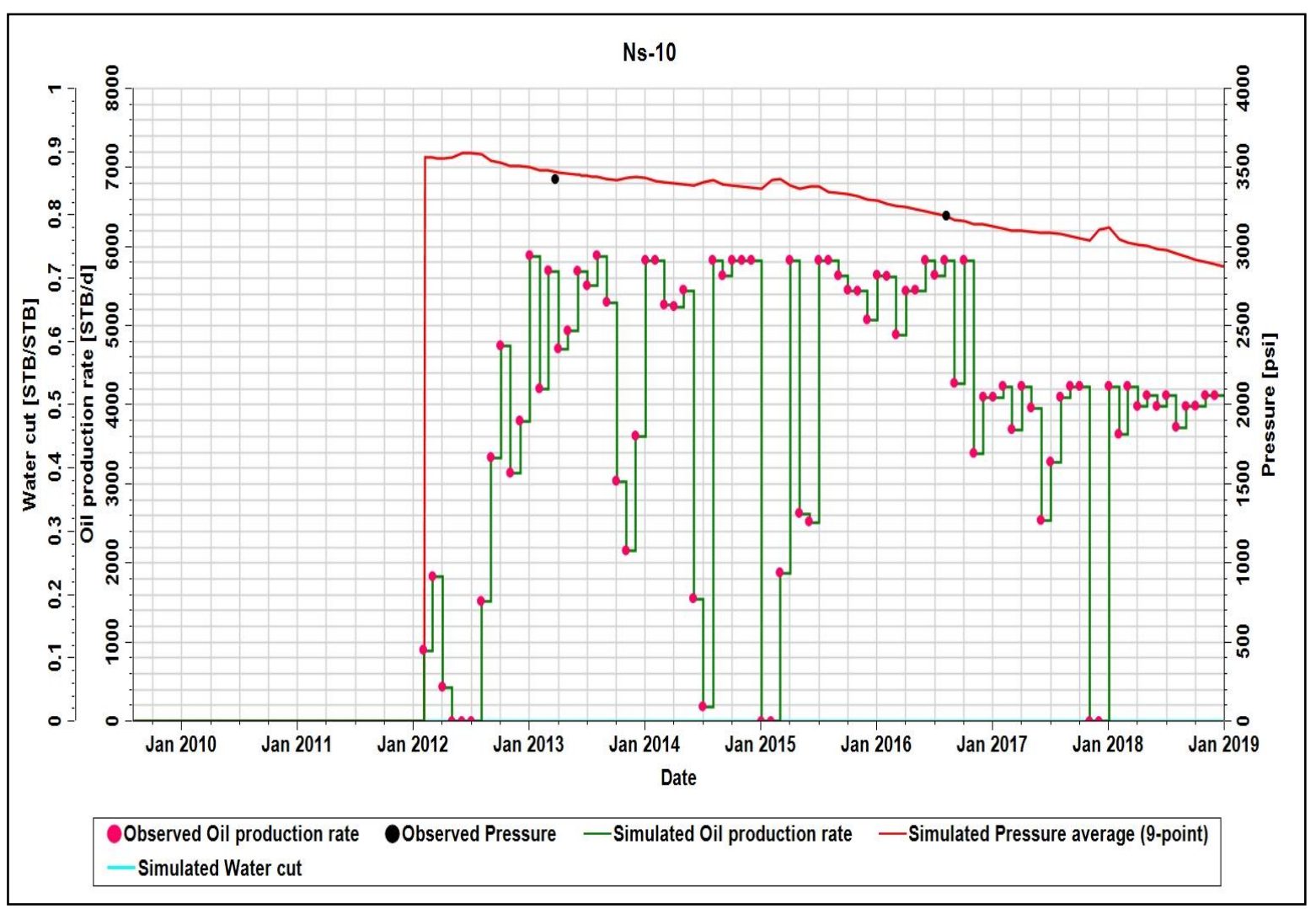

Fig. 12. History matching for well NS-10

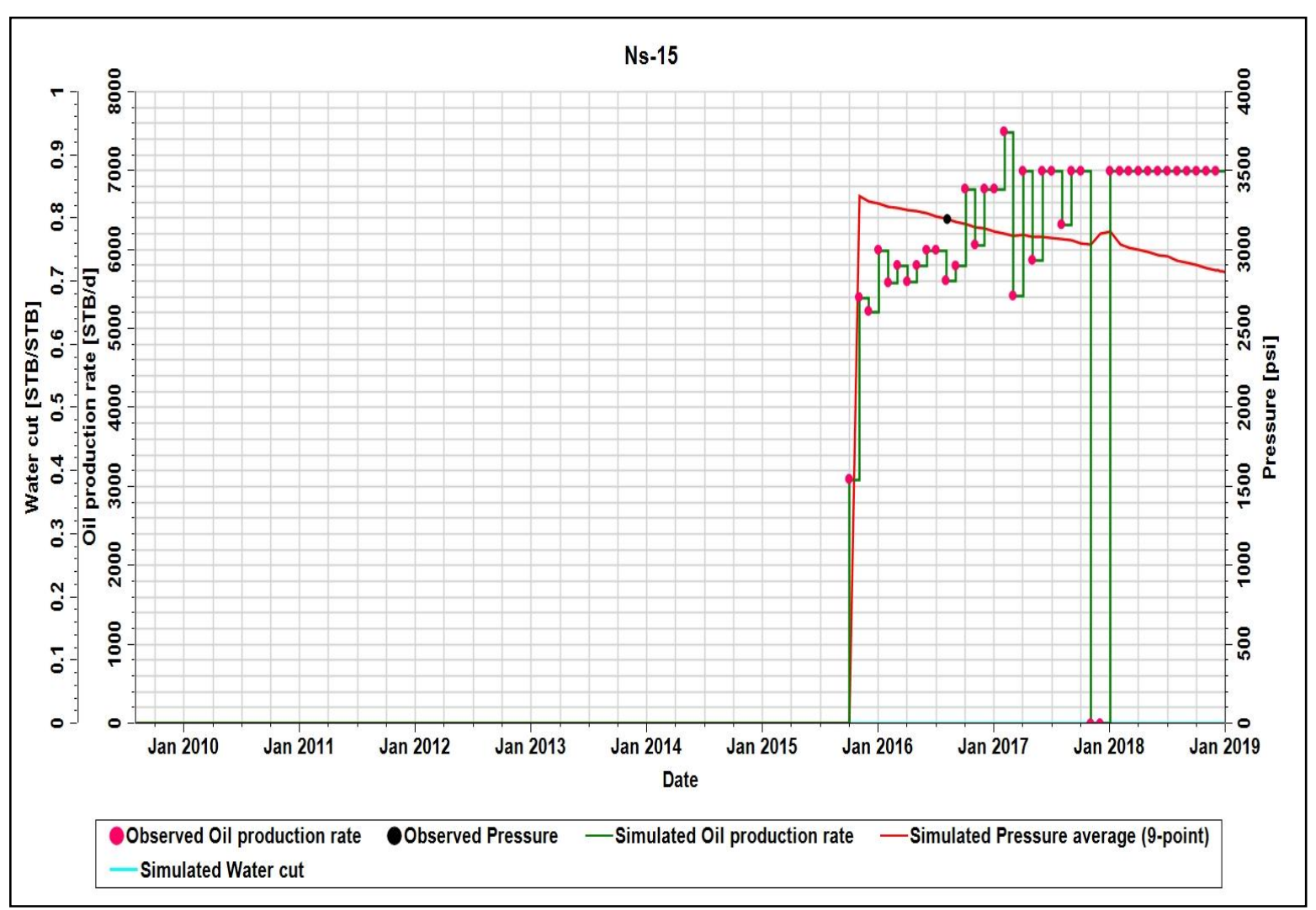

Fig. 13. History matching for well NS-15 


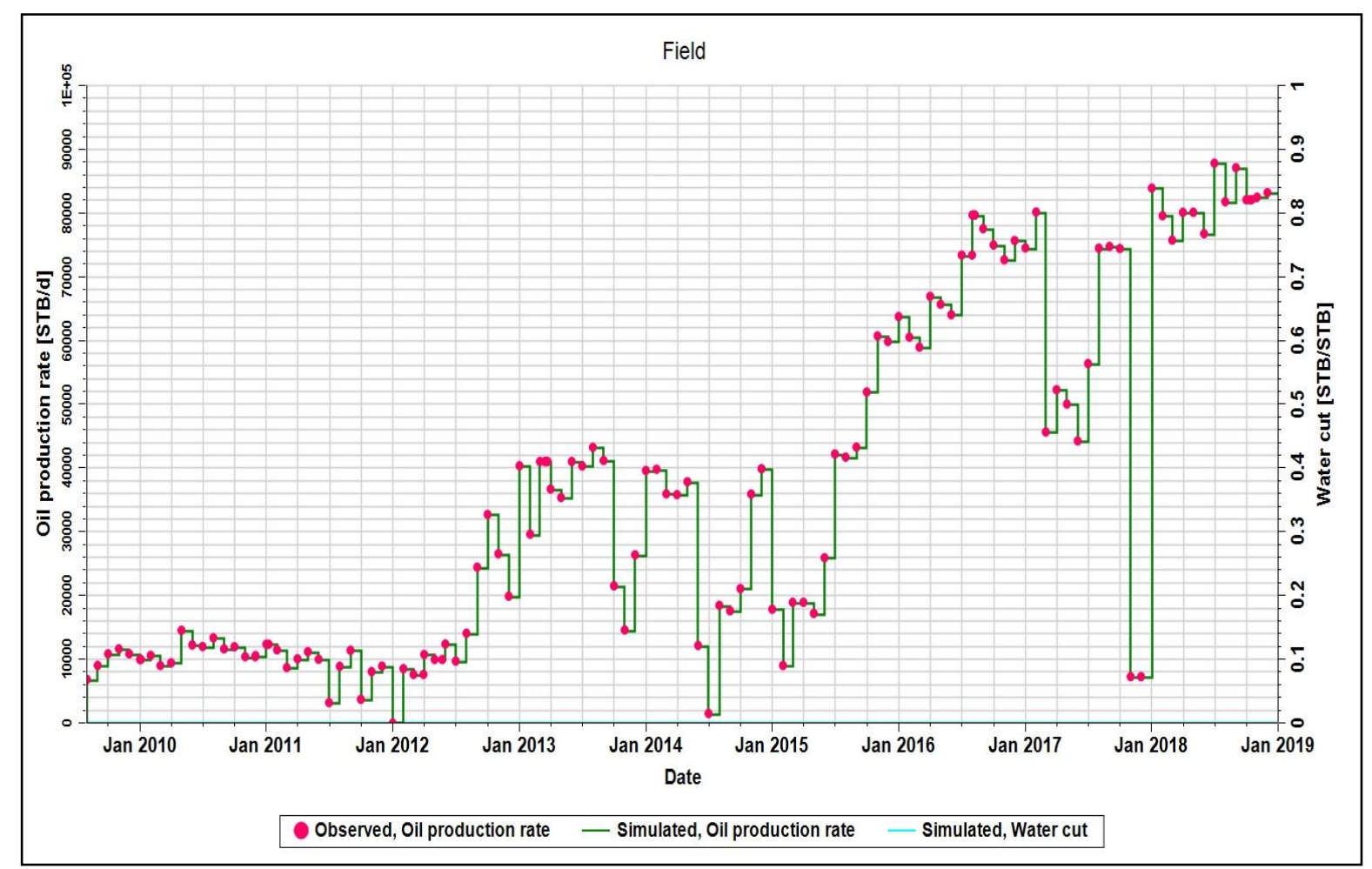

Fig. 14. History matching of field production

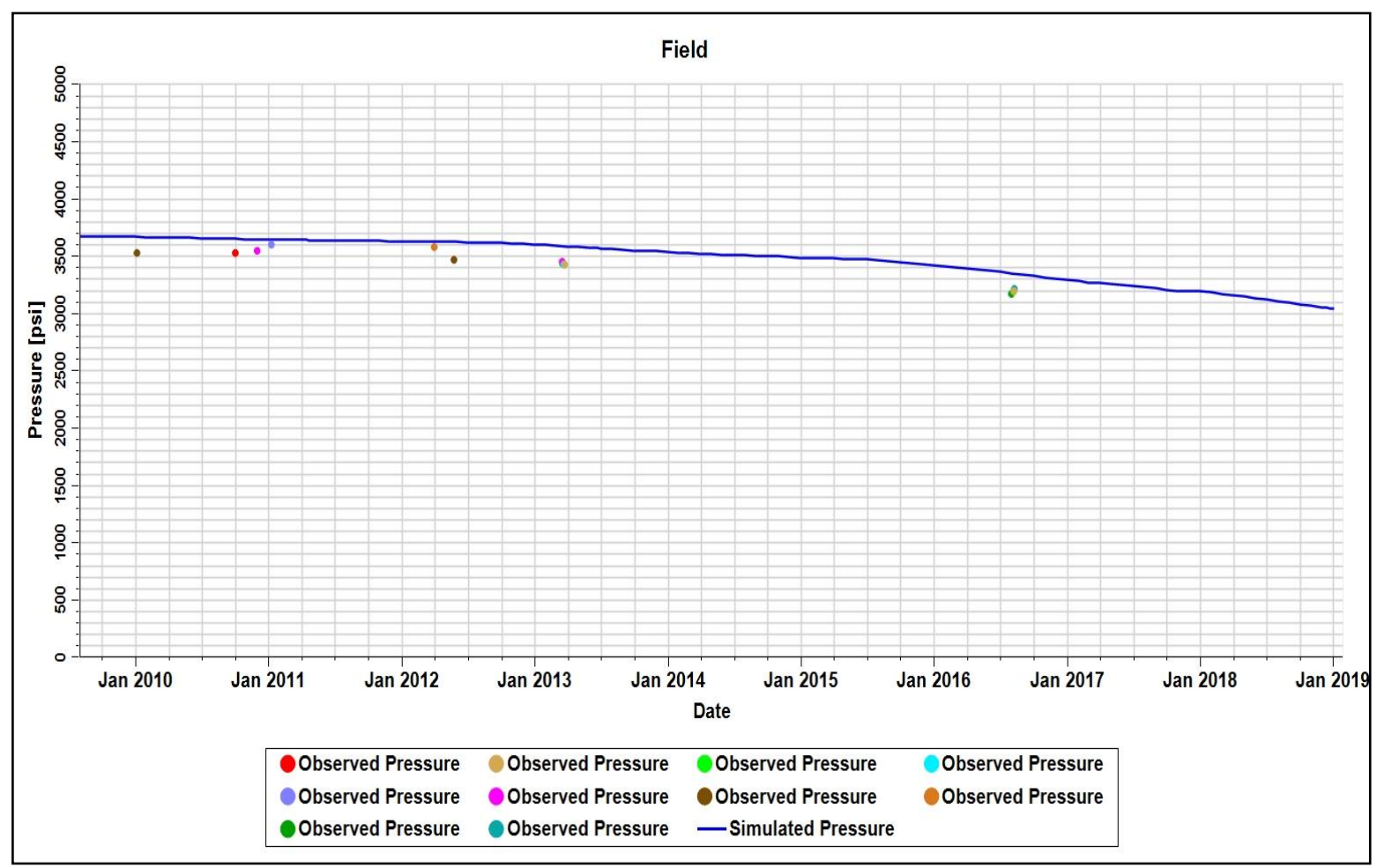

Fig. 15. History matching of field pressure 


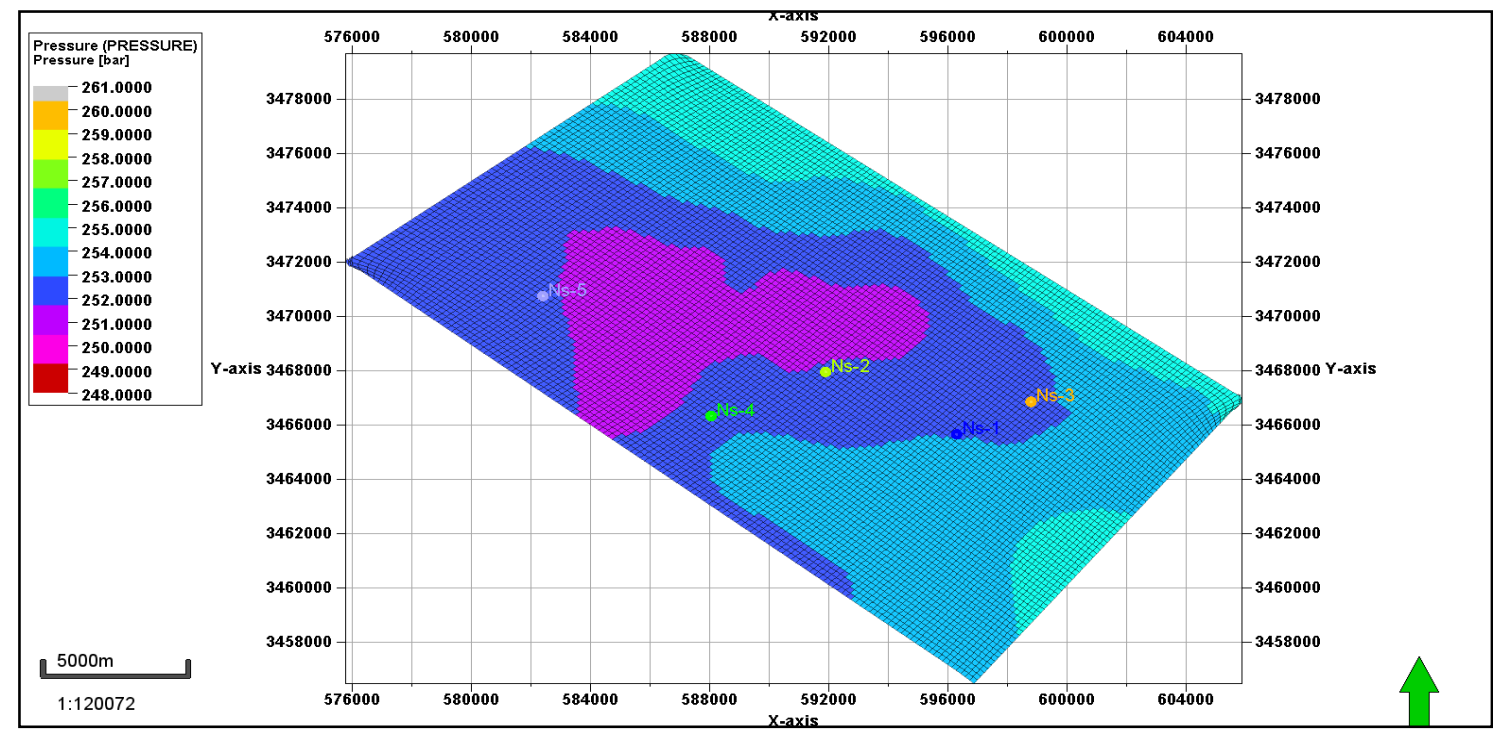

Fig. 16. Initial pressure of the field

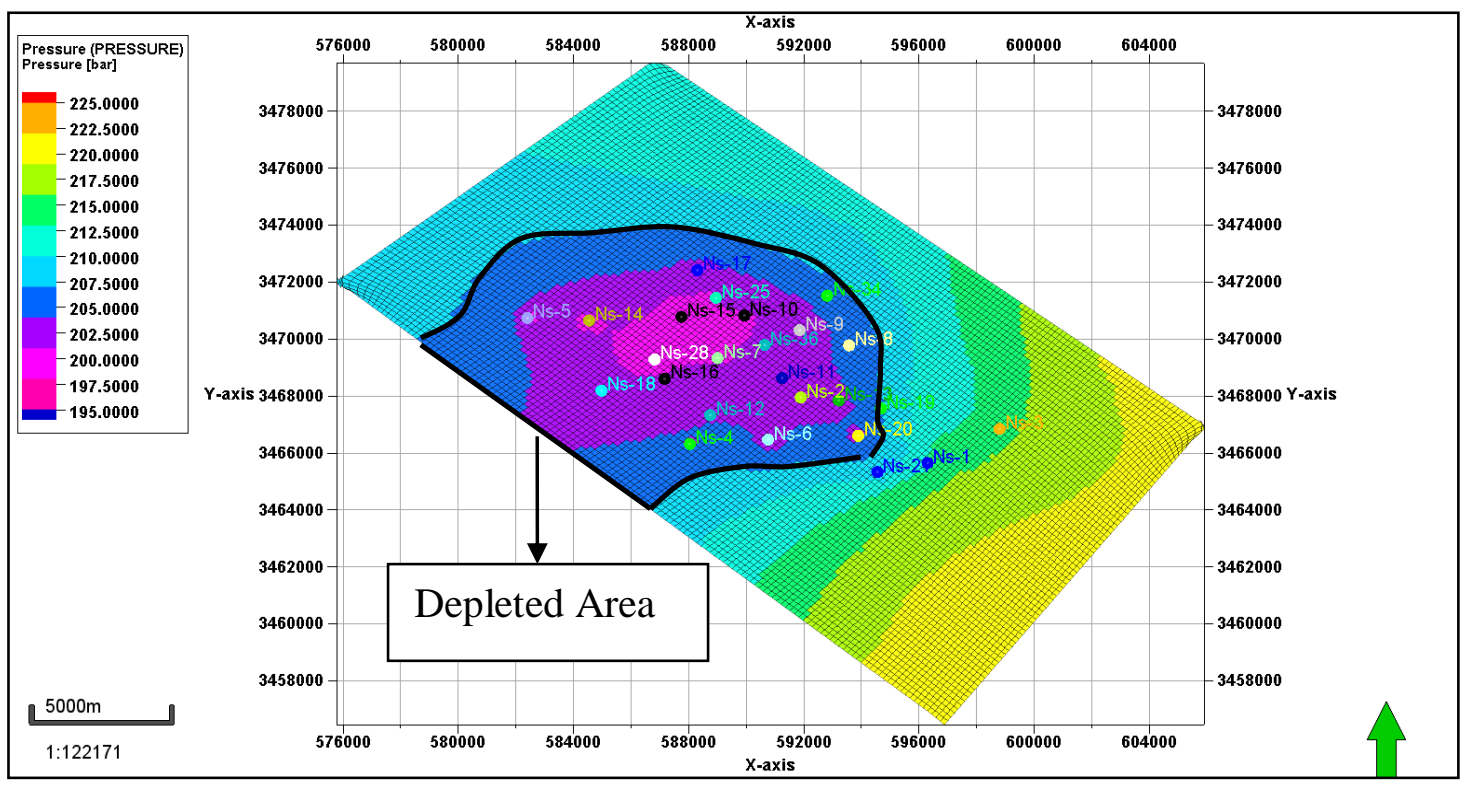

Fig. 17. Pressure distribution of the field at the end of the period of history matching (at the end of 2018)

\section{CONCLUSIONS}

The difference between OIIP calculated from the geological model and the reservoir model may belong to the fact that the geological model utilized water saturation values resulted from computer processing interpretation (CPI) of well logs after distributing, also the geological model does not account for the rock compressibility in its effect on porosity, while the reservoir model used water saturation resulted from core analysis and rock compressibility used in its calculation. The reservoir behavior indicates that the main mechanism drive is 
solusion gas drive where the reservoir has a weak bottom aquifer or no aquifer. Good matching of well pressures is obtained after modifying the horizontal permeability

\section{NOMENCLATURE}

$\mathrm{B}_{\mathrm{w}}=$ water formation volume factor, bbl/STB

$\mathrm{Cf}=$ Formation compressibility, $\mathrm{psi}^{-1}$

$\mathrm{CL}^{-1}=$ chloride ion, $\mathrm{ppm}$.

$\mathrm{C}_{\mathrm{w}}=$ coefficient of isothermal compressibility of water, $\mathrm{psi}^{-1}$

$\mathrm{P}=$ Pressure, psia

$\mathrm{R}_{\mathrm{w}}=$ Water resistivity, ohm.m

$\mathrm{S}=$ salinity, $\mathrm{mg} / \mathrm{L}$

$\mathrm{T}=$ Temperature, ${ }^{\circ} \mathrm{F}$

TDS $=$ Total dissolved salt, $\mathrm{ppm}$

$\phi=$ Porosity, fraction

\section{REFERENCES}

Abbas, L. K., and Mahdi, T. A., 2020. Reservoir modeling of Mishrif Formation in Majnoon oilfield, Southern Iraq. Iraqi Geological Journal, 35(1E): 89-101.

Ahmed, T., 2019. Reservoir Engineering Handbook, fifth ed. Gulf Professional Publishing.

Al-Baldawi, B. A., 2020. Determination of pore types and porosity trends using of velocity-deviation log for the carbonate Mishrif reservoir in Halfaya oilfield, Southeast Iraq. Iraqi Geological Journal, 35(1D): 26-37.

Al-Mimar, H. S., Awadh, S. M., Al-Yaseri, A. A., and Yaseen, Z. M., 2018. Sedimentary units-layering system and depositional model of the carbonate Mishrif reservoir in Rumaila oilfield, Southern Iraq, Modeling Earth Systems and Environment, springer, doi.org/10.1007/s40808-018-0510-5.

Eni Company, 2007. Sedimentological and Facial Analysis. ENI Exploration and Production Division.

Exploration Oil Company (EOC), 2001. Detailed Geological Assessment Study of Mishrif Formation in Nasiriyah OilField.

Gilman, J. R., and Ozgen, C., 2013. Reservoir Simulation: History Matching and Forecasting. Richardson, TX: Society of Petroleum Engineers, USA, 109 pp.

Islam, M. R., Hossain, M. E., Mousavizadegan, S. H., Mustafiz, S., and Abou-Kassem, J. H., 2016. Advanced Petroleum Reservoir Simulation: towards developing reservoir emulators, second ed. John Wiley and Sons, Canada .

Kortekaas, F. M., 1998. Acquisition of reservoir data and their incorporation in the construction and updating of dynamic, integrated reservoir models. In 15th World Petroleum Congress. World Petroleum Congress.

Mattax, C. C., and Dalton, R. L., 1990. Reservoir simulation (includes associated papers 21606 and 21620). Journal of Petroleum Technology, 42 (06): 692-695.

McCain Jr, W. D., 1991. Reservoir-fluid property correlations-state of the art (includes associated papers 23583 and 23594). SPE Reservoir Engineering, 6(02): 266-272,

Satter, A., and Iqbal, G. M., 2016. Reservoir Engineering: The Fundamentals, Simulation, and Management of Conventional and Unconventional Recoveries. Gulf Professional Publishing. 